\title{
Fast method to determine the elements in maize flour: reduction in preparation time and reagent consumption
}

\author{
Método rápido de determinação de elementos em farinha de milho: redução do tempo \\ de preparação e consumo de reagente
}

\author{
Irineo Kelte Filho ${ }^{1 *}$, Mariane Butik¹, Ana Caroline Jaski', Sueli Pércio Quináia ${ }^{1}$ \\ ${ }^{1}$ Universidade Estadual do Centro-Oeste (UNICENTRO), Guarapuava/PR - Brazil

\section{*Corresponding Author} \\ Irineo Kelte Filho, Universidade Estadual do Centro-Oeste (UNICENTRO), Rua Simeão Varela de Sá, 3, Vila Carli, CEP: 85040-080, \\ Guarapuava/PR - Brazil, e-mail: i_r_i_n_e_o@hotmail.com
}

Cite as: Fast method to determine the elements in maize flour: reduction in preparation time and reagent consumption. Braz. J. Food Technol., v. 21, e2017091, 2018

Received: Mar. 07, 2017; Accepted: Aug. 04, 2017

\section{Abstract}

The aim of this work was to develop and validate methodology to reduce the digestion time and reagent consumption in the determination of minerals in maize flour. The standard methodology employed in Brazil is that described by AOAC. It consists of the calcination of the sample at high temperatures for a long period of time, making the process expensive and slow. In this work, a wet sample digestion method using $\mathrm{HNO}_{3}$ was employed, heating on a block digester with final dissolution in an ultrasonic bath. The validation tests involved linearity and working range studies, and the determination of the detection and quantification limits, accuracy and precision. The sample digestion time was 1:30 $\mathrm{h}$ and the percent recoveries for the metals were $93 \%$ for $\mathrm{Ca}, 98 \%$ for $\mathrm{Cu}, 110 \%$ for Fe, $97 \%$ for $\mathrm{Mg}, 101 \%$ for $\mathrm{Mn}$ and $106 \%$ for $\mathrm{Zn}$.

Keywords: Metals; Maize flour; Acid digestion; Sonification.

\section{Resumo}

O objetivo deste trabalho consiste em desenvolver e validar uma metodologia que reduza o tempo de digestão e o consumo de reagentes para determinar minerais em farinha de milho. No Brasil, a metodologia padrão utilizada é a descrita pelo AOAC, que consiste na calcinação da amostra em altas temperaturas, por longo período, o que torna o processo dispendioso e moroso. Neste trabalho, aplicou-se a digestão por via úmida das amostras usando $\mathrm{HNO}_{3}$, aquecimento em bloco digestor e solubilização final em banho ultrassom. Os testes de validação envolveram estudos de linearidade e faixa de trabalho, limites de detecção e de quantificação, precisão e exatidão. O tempo de digestão das amostras foi de 1h30min e as porcentagens de recuperação dos metais foram de 93\% para Ca, 98\% para Cu, 110\% para Fe, 97\% para Mg, 101\% para $\mathrm{Mn}$ e $106 \%$ para Zn.

Palavras-chave: Metais; Farinha de milho; Digestão ácida; Sonificação.

\section{Introduction}

Maize is one of the most widely grown cereals on the planet, being the second most widely cultivated crop in Brazil (SCHWANZ et al., 2012). According to CONAB (2015) ("Brazilian Supply Company"), in Brazil maize production was 54.5 million tons in 2015, with significant amounts being produced by agriculturists in the central-south region of the country. Maize is an energy-rich food, including vitamins A and the complex $\mathrm{B}$, proteins, fats, carbohydrates, $\mathrm{Ca}, \mathrm{Fe}, \mathrm{P}$ and starch in its composition (ABIMILHO, 2015). Since it is very nutritious, the processing of maize provides several derivatives that are used in both human and animal feed and one of these products is maize flour. Although the fraction of maize destined for human consumption is smaller, maize flour is often used in Brazilian culinary, when making cakes, bread, cookies and other baked foods (BASTOS, 1987).

Although there is some research on the chemical composition of maize (CALLEGARO et al., 2005; FERREIRA et al., 2001), there is a lack of research in Brazil on the concentration of 
minerals in maize flours. In general, the official methods to determine minerals in flour involve the complete digestion of the sample in a dry process, or ashing (CUNNIFF, 1997). Ciobanu et al. (2013) determined $\mathrm{Cd}$ and $\mathrm{Pb}$ in several types of food sold in Nabertherm in Germany, including maize and wheat flours. The procedure employed in the preparation of the samples consisted of the drying of $20 \mathrm{~g}$ to $30 \mathrm{~g}$ of each sample overnight at $105^{\circ} \mathrm{C}$ followed by calcination at $450^{\circ} \mathrm{C}$. The residue was treated with $5 \mathrm{~mL}$ of $\mathrm{HNO}_{3}$ and kept in a sand bath at $150{ }^{\circ} \mathrm{C}$ to dissolve the remaining ash. Fatoki and Bamiro (1990) calcined maize flour samples at $450{ }^{\circ} \mathrm{C}$ for $16 \mathrm{~h}$ to determine the $\mathrm{Na}, \mathrm{K}$, $\mathrm{Ca}$ and $\mathrm{Mg}$ contents in infant food. Santos et al. (2004) proposed the calcination of food samples (vegetables, fruits, roots, grains, cereals, sugar, coffee, cassava flour, wheat flour, maize flour, pasta, meat, fish, milk), in a muffle furnace at $400{ }^{\circ} \mathrm{C}$ for $24 \mathrm{~h}$, to determine the $\mathrm{Al}, \mathrm{Cd}, \mathrm{Cr}$, $\mathrm{Cu}, \mathrm{Mn}, \mathrm{Ni}, \mathrm{Pb}, \mathrm{U}$ and $\mathrm{Zn}$ contents. Tejera et al. (2013) carried out a previous digestion of $10 \mathrm{~g}$ of wheat flour with $2 \mathrm{~mL}$ of concentrated $\mathrm{HNO}_{3}$ and then calcined the sample at $450{ }^{\circ} \mathrm{C}$ for $48 \mathrm{~h}$. The resulting ash was moistened with some drops of $\mathrm{HNO}_{3}$, heated until the acid evaporated, and then heaten again in the furnace to obtain white ash. The elements quantified in the wheat flour ash were $\mathrm{Na}, \mathrm{K}$, $\mathrm{Mg}, \mathrm{Ca}, \mathrm{Mn}, \mathrm{Fe}, \mathrm{Cu}, \mathrm{Zn}, \mathrm{Cr}, \mathrm{Ni}, \mathrm{Cd}$ and $\mathrm{Pb}$. Pourhossein and Shalaei (2016) determined Fe in samples of wheat and maize after their calcination in a muffle furnace at $600{ }^{\circ} \mathrm{C}$ for $10 \mathrm{~h}$, adding $10 \mathrm{~mL}$ of $\mathrm{HCl}(1 \mathrm{M})$ to the resulting ash, neutralizing with $10 \mathrm{~mL}$ of $\mathrm{NaOH}$, and then completing the volume to $100 \mathrm{~mL}$.

The lengthy preparation time of the food samples involved in the use of calcination and inadequate temperature control, may generate contamination of the samples or even the loss of elements by volatilization, making the chemical analyses unreliable. Thus several articles have presented the option of digesting the food in closed environments, making use of microwave ovens. Algül and Kara (2014) used a microwave oven to digest $0.25 \mathrm{~g}$ of maize flour from Turkey employing two heating cycles during the digestion process, with a total of $43 \mathrm{~min}$ at an output of $1600 \mathrm{~W}$. The samples were digested in Teflon vessels with $5 \mathrm{~mL}$ of $\mathrm{HNO}_{3}(65 \%)$ and $2 \mathrm{~mL}$ of $\mathrm{H}_{2} \mathrm{O}_{2}(30 \%)$ and $\mathrm{Pb}, \mathrm{Cd}, \mathrm{Hg}$, As, $\mathrm{Cu}, \mathrm{Zn}$ and $\mathrm{Cr}$ determined in the digested material. Hongxing and Yu-Kui (2012) determined K, Mg, Ca, Fe, $\mathrm{Zn}, \mathrm{Mn}, \mathrm{Cu}, \mathrm{Mo}$ and $\mathrm{Li}$ in wheat, maize and soybean from Peking, China, after digesting in a microwave oven (1200 W, 300 psi) for 30 min.

Although these techniques were efficient and showed analytical agility, conventional wet digestion methods in the presence of acids and oxidants, using cheaper heating techniques with heating plates or block digesters, are still being investigated. Boen et al. (2007) measured the concentration of $\mathrm{Fe}$ and $\mathrm{Zn}$ in enriched wheat and maize flours. Both types of flour ( $\sim 0.2 \mathrm{~g}$ to $0.3 \mathrm{~g}$ ) were transferred to digestion tubes containing $2 \mathrm{~mL}$ of concentrated $\mathrm{HNO}_{3}$. Glass funnels were adapted to the tubes of the block digester, making reflux of the acid steam easier. The tubes were heated at $100{ }^{\circ} \mathrm{C}$ for $2 \mathrm{~h}$, then cooled, $1 \mathrm{~mL}$ of $\mathrm{H}_{2} \mathrm{O}_{2}$ added, and the temperature adjusted to $100{ }^{\circ} \mathrm{C}$ again and maintained for $30 \mathrm{~min}$. The temperature was then raised to $130^{\circ} \mathrm{C}$ and maintained for one more hour. The digested product was then cooled, diluted and maintained in an ultrasonic bath for a few seconds. Santos et al. (2015) carried out a study on the homogeneity of the wheat flour samples in order to obtain reference material to ensure reliability of the measurements of the nine elements. For this purpose, $2.0 \mathrm{~g}$ of sample were inserted into digestion tubes containing $2.0 \mathrm{~mL}$ of $\mathrm{HNO}_{3}$ and $1.0 \mathrm{~mL}$ of $\mathrm{H}_{2} \mathrm{O}_{2}$, and the mixture heated on a block digester until a clear solution was obtained.

In the present research, digestion techniques were prioritized as a wet method, with the aim of reducing the preparation time and reagent consumption as compared to the other quantification methodologies. A method was optimized and validated for the sample preparation of maize flours of the "biju" and flake types, with a view to determining the minerals $\mathrm{Ca}, \mathrm{Cu}, \mathrm{Fe}, \mathrm{Mg}, \mathrm{Mn}$ and $\mathrm{Zn}$ by flame atomic absorption spectroscopy.

\section{Material and methods}

\subsection{Equipment and reagents}

The analyses of the metal elements were carried out using a Varian Flame Atomic Absorption Spectrometer (FAAS), model Spectra AA-220, which contains hollow-cathode lamps as the radiation source (Varian and Agilent), and a deuterium lamp to correct the background noise. Table 1 shows the instrumental parameters for the measurements by FAAS. A block digester (Alkafit, AT 509), analytical balance (Shimadzu, model AY220) with an accuracy of $\pm 0.0001 \mathrm{~g}$, and ultrasonic equipment (Spencer, model CD-4800) were also used.

Standard solutions of $\mathrm{Ca}, \mathrm{Cu}, \mathrm{Fe}, \mathrm{Mg}, \mathrm{Mn}$ and $\mathrm{Zn}$ (1000 $\mathrm{\mu g} / \mathrm{mL}$ P.A. - BIOTEC) were used to prepare the analytical curves. All the reagents employed were of analytical degree, and the solutions were prepared using deionized water obtained using a Gehaka OS 10LX system. Nitric acid (Carlo Erba, 65\%) and hydrogen peroxide (BIOTEC 35\%) were also employed. All the material handled, such as

Table 1. Instrumental parameters of the FAAS

\begin{tabular}{ccccc} 
Metal & $\lambda(\mathbf{n m})$ & $\mathbf{i}(\mathbf{m A})$ & slit(nm) & Flame \\
$\mathrm{Ca}$ & 422.7 & 10 & 0.5 & $\mathrm{~N}_{2} \mathrm{O} / \mathrm{C}_{2} \mathrm{H}_{2}$ \\
$\mathrm{Cu}$ & 324.7 & 4 & 0.5 & air $/ \mathrm{C}_{2} \mathrm{H}_{2}$ \\
$\mathrm{Fe}$ & 248.3 & 5 & 0.2 & air $/ \mathrm{C}_{2} \mathrm{H}_{2}$ \\
$\mathrm{Mn}$ & 279.5 & 5 & 0.2 & air $/ \mathrm{C}_{2} \mathrm{H}_{2}$ \\
$\mathrm{Zn}$ & 213.9 & 5 & 1.0 & air $/ \mathrm{C}_{2} \mathrm{H}_{2}$ \\
$\mathrm{Mg}$ & 285.2 & 4 & 0.5 & air $/ \mathrm{C}_{2} \mathrm{H}_{2}$ \\
\hline
\end{tabular}


Fast method to determine the elements in maize flour: reduction in preparation time and reagent consumption Kelte Filho, I. et al.

vessels, glasses and jars, was properly decontaminated in a $5 \%(v / v)$ nitric acid bath for 24 hours, and then rinsed three times with deionized water.

\subsection{Maize flour samples}

Samples of yellow maize flour of the "biju" and flake types were used, purchased on the local market in Guarapuava - Paraná State, Brazil. The maize flours were placed in decontaminated plastic jars, labeled and stored in a cool, ventilated area. The samples were ground using a mortar and plastic pestle to decrease the particle size in order to facilitate the sample weighing and digestion processes, and then sifted through a $1.0 \mathrm{~mm}$ (16 mesh) sieve. All the analyses were carried out in triplicate.

\subsection{Optimization of the procedure for the digestion of maize flour}

Six different procedures of acid digestion were tested to assess the efficiency of the decomposition of the yellow maize flour, varying the digestion jars, reagent volumes and heating techniques. The digestion of "blank" solutions was carried out for each of the sample digestion procedures assessed. Table 2 shows the experimental conditions applied for each digestion procedure. The screw caps of the glass tubes (procedures 4 to 6) were replaced by the ferrules of micropipettes to minimize contamination from the caps and provide a steam reflux system during heating. The resulting sample from each digestion process was diluted with deionized water in a $10 \mathrm{~mL}$ volumetric flask, after cooling.

\subsection{Validation of the methodology to determine $\mathrm{Ca}$, $\mathrm{Cu}, \mathrm{Fe}, \mathrm{Mg}, \mathrm{Mn}$ and $\mathrm{Zn}$ in maize flour samples}

To validate the best analytical procedure proposed involving digestion using a wet method and the determination of minerals by FAAS in maize flour samples, the following parameters were assessed: linearity, detection and quantification limits, accuracy and precision.

External calibration curves were used, prepared in triplicate, using standard solutions of each metal in the following concentration ranges: from 0.3 to $3.0 \mathrm{mg} \mathrm{Ca} / \mathrm{L}$, from 0.1 to $1.0 \mathrm{mg} \mathrm{Cu} / \mathrm{L}$, from 0.5 to $4.0 \mathrm{mg} \mathrm{Fe} / \mathrm{L}$, from 0.2 to $1.0 \mathrm{mg} \mathrm{Mg} / \mathrm{L}$, from 0.1 to $1.0 \mathrm{mg} \mathrm{Mn/L}$ and from 0.1 to $1.0 \mathrm{mg} \mathrm{Zn/L}$. In order to check the linearity of the analytical curves, an analysis of the linear regression and a test for the lack of fit were carried out, with a confidence level of $95 \%$. The detection and quantification limits were calculated using the Analytical Curve method, in accordance with the $\mathrm{ICH}$ (1996). The accuracy of the method was determined based on the study of repetitiveness (on the same day) and the intermediate accuracy (triplicates of the samples measured on three consecutive days) (LATIMER JUNIOR, 2012). The precision of the method was assessed from studies of the addition and recovery of the analyte. The maize flour samples (in triplicate) were reinforced with the minerals ( $\mathrm{Ca}, \mathrm{Cu}, \mathrm{Fe}, \mathrm{Mg}, \mathrm{Mn}$ and $\mathrm{Zn}$ ) at two concentration levels $(0.5$ and $1.0 \mathrm{mg} / \mathrm{L})$ (NATA, 2012). The statistical analysis applied for the validation of the method was carried out at a confidence level of 95\%, using the statistical software Action Free, version 2.7.

\section{Results and discussion}

\subsection{Optimization of the digestion process}

The sample preparation stage is one of the most important ones during the determination of metals in complex samples. The procedures employed in the preparation process depend a lot on the nature of the sample and the concentration of the elements to be determined. Another important factor to be taken into consideration in the selection of the decomposition method for a sample is the kind of technique that will be applied to quantify the analyte. Dry sample decomposition techniques, that is, by calcification, present a series of inconveniences, such as risks of contamination, loss of volatile analytes and the considerable amount of time spent on eliminating organic matter, making the process very slow (SANTOS et al., 2015). Therefore, procedures which reduce the preparation time and allow for the analysis of a larger number of samples are noteworthy.

In this work, six wet procedures of sample digestion were assessed with the aim of minimizing contamination

Table 2. Experimental conditions applied in the different yellow maize flour digestion procedures.

\begin{tabular}{|c|c|c|c|c|c|c|}
\hline Procedure & Digestion Bottle & Mass (g) & $\mathrm{HNO}_{3} ; \mathrm{H}_{2} \mathrm{O}_{2}(\mathrm{~mL})$ & Heating technique & $\mathrm{T}\left({ }^{\circ} \mathrm{C}\right)$ & Time (h) \\
\hline 1 & cryogenic tube $(5 \mathrm{~mL})$ & 0.1 & $2.5 ; 1.5$ & boiling water bath & 60 & 04:00:00 \\
\hline 2 & falcon tube $(50 \mathrm{~mL})$ & 0.3 & $4.0 ; 1.0$ & boiling water bath & 60 & 04:00:00 \\
\hline 3 & falcon tube (15 mL) & 0.3 & $5.0 ; 2.0$ & boiling water bath & 80 & 04:00:00 \\
\hline 4 & glass tube (10 mL) & 0.3 & $5.0 ; 0.5$ & block digester & 120 & 01:00:00 \\
\hline 5 & glass tube $(10 \mathrm{~mL})$ & 1 & 5.0; without $\mathrm{H}_{2} \mathrm{O}_{2}$ & block digester & 150 & 01:00:00 \\
\hline 6 & glass tube $(10 \mathrm{~mL})$ & 0.5 & 5.0; without $\mathrm{H}_{2} \mathrm{O}_{2}$ & $\begin{array}{l}\text { block digester; } \\
\text { ultrasonic equipment }\end{array}$ & $\begin{array}{c}60 \\
90 \\
130\end{array}$ & $\begin{array}{l}00: 05 \\
00: 05 \\
01: 00 \\
00: 24\end{array}$ \\
\hline
\end{tabular}


and the loss of analytes, and also of decreasing the volume of oxidant reagents. Table 3 shows the percent recoveries of the metals $\mathrm{Ca}, \mathrm{Cu}, \mathrm{Fe}, \mathrm{Mg}, \mathrm{Mn}$ and $\mathrm{Zn}$ in samples initially doped with $1 \mathrm{mg} / \mathrm{L}$ of each metal, for each procedure assessed.

In procedure 1 (Table 2) cryogenic tubes were used with their respective caps in order to avoid sample losses during the heating period. However, visually, it was noted that the digestion was not complete and that the volume of the tube was not satisfactory for the process, since small solid particles adhered to the internal walls of the caps. The recovery values found for $\mathrm{Ca}, \mathrm{Cu}, \mathrm{Fe}, \mathrm{Mg}, \mathrm{Mn}$ and Zn were 81.3\%, 73.6\%, 96.0\%, 72.8\%, 76.2\% and $75.5 \%$, respectively. These low recovery values suggest that incomplete digestion may have occurred. In procedure 2, the cryogenic tubes $(5 \mathrm{~mL}$ ) were substituted by Falcon tubes $(50 \mathrm{~mL})$. The digested sample had a better appearance when compared to procedure 1, but there were still some maize fiber particles suspended in the solution. In this case, the percent recoveries varied from $78.0 \%$ to $112.0 \%$ indicating there was some improvement in the process. In procedure 3, the reagent volumes were altered and also the Falcon tubes. The digested sample showed an even better appearance than in the two previous procedures; however the metal recoveries were still not satisfactory, varying from $74.7 \%$ to $127.0 \%$. In these first three procedures a heating plate was used as the heat source. It was noted that the temperature of the heating plate was insufficient for the digestion of the flours, even when using higher volumes of the oxidant agent. Therefore a temperature controlled block digester was used for the other experiments.

In procedures 4 to 6 glass tubes of $10 \mathrm{~mL}$ were used and the original caps were replaced by the ferrules of micropipettes, since in previous studies, carried out by the present research group, contamination of the samples by $\mathrm{Zn}$, originated from the caps of the glass tubes, was confirmed. Since the ferrules have a small orifice, they allowed for the release of pressure from the system, as well as acting as a gas reflux apparatus inside the tube during digestion. In procedure 4 the metals presented recovery values between $72.0 \%$ and $125.0 \%$. However in this procedure, the presence of hydrogen peroxide and the high temperature $\left(120^{\circ} \mathrm{C}\right)$ resulted in considerable effervescence in the opening of the glass tube, generating sample loss. In procedure 5, only $\mathrm{HNO}_{3}$ was used and a larger sample mass $(1 \mathrm{~g})$, to avoid effervescence during digestion. However, the recoveries of $\mathrm{Fe}$ and $\mathrm{Cu}$ were not satisfactory. In procedure 6 , hydrogen peroxide was again excluded from the digestion, and a heating ramp applied during the process, the temperature being held at $60{ }^{\circ} \mathrm{C}$ and $90^{\circ} \mathrm{C}$ for 5 min each, and then at $130{ }^{\circ} \mathrm{C}$ for $1 \mathrm{~h}$. The heating ramp prevented the sudden boiling of the material, as well as sample loss. After digestion, small particles were still visible in the solution, after being diluted to $10 \mathrm{~mL}$. However, when the solution was maintained in an ultrasonic bath for $24 \mathrm{~min}$, the remains of the suspended material were eventually dissolved. Dissolution was thus fully completed, the ultrasonic equipment intensely agitating the molecules present in the solution, such that the remaining small solid particles finally dissolved. With this procedure the recovery varied from $93.0 \%$ to $110.0 \%$.

As observed in Table 3, procedure 6 presented excellent recovery efficiency for all the metals assessed, requiring a relatively short digestion time $(\sim 1: 30 \mathrm{~h})$ when compared to other studies cited in the literature (Table 4).

After optimization of the sample preparation procedure, the linearity of the analytical curves was assessed for each metal determined, and also the LD and LQ values (Table 5). Table 5 shows significantly linear models for the concentration ranges assessed, since the $F$ values were higher than the $F$ value $=4.67$, and $p<0.05$ at a confidence level of $95 \%$. The curves did not present

Table 3. Recovery of minerals (1 mg/L) in maize flour after distinct digestion processes.

\begin{tabular}{|c|c|c|c|c|c|c|}
\hline \multirow{2}{*}{$\begin{array}{l}\text { Digestion } \\
\text { Procedure }\end{array}$} & \multicolumn{6}{|c|}{$\%$ Recovery } \\
\hline & $\mathrm{Ca}$ & $\mathrm{Cu}$ & $\mathrm{Fe}$ & Mg & Mn & $\mathbf{Z n}$ \\
\hline 1 & $81.3 \pm 6.8$ & $73.6 \pm 1.6$ & $96.0 \pm 11.0$ & $72.8 \pm 9.4$ & $76.2 \pm 9.3$ & $75.5 \pm 2.1$ \\
\hline 2 & $80.0 \pm 7.1$ & $94.0 \pm 1.1$ & $112.0 \pm 8.3$ & $83.6 \pm 6.8$ & $80.4 \pm 1.8$ & $78.0 \pm 8.5$ \\
\hline 3 & $108.0 \pm 7.5$ & $77.0 \pm 6.3$ & $78.0 \pm 2.4$ & $127.0 \pm 3.2$ & $87.7 \pm 7.9$ & $74.7 \pm 6.4$ \\
\hline 4 & $72.0 \pm 8.7$ & $85.0 \pm 4.1$ & $88.5 \pm 11.2$ & $87.0 \pm 5.7$ & $102.0 \pm 2.6$ & $125.0 \pm 2.3$ \\
\hline 5 & $107.0 \pm 3.8$ & $83.0 \pm 9.3$ & $73.0 \pm 2.2$ & $114.0 \pm 5.8$ & $114.0 \pm 4.8$ & $120.0 \pm 0.3$ \\
\hline 6 & $93.0 \pm 3.82$ & $98.0 \pm 1.2$ & $110.0 \pm 5.3$ & $97.0 \pm 2.4$ & $101.0 \pm 1.3$ & $106.0 \pm 2.5$ \\
\hline
\end{tabular}

Table 4. Wet digestion procedures for maize flour samples and derivatives.

\begin{tabular}{lllc}
\multicolumn{1}{c}{ Sample } & Digestion & Digestion time(h) & Reference \\
Biju and flaked maize flour & $\mathrm{HNO}_{3}$ & $1: 30 \mathrm{~h}+$ ultrasonic sonification & This work \\
Maize chips & $\mathrm{H}_{2} \mathrm{O}_{2}: \mathrm{HNO}_{3} 48 \mathrm{~h}$ rest + heating to a clear solution + sonification & Hariri et al. (2015) \\
Maize and wheat flours & $\mathrm{H}_{2} \mathrm{O}_{2}: \mathrm{HNO}_{3} 3: 30 \mathrm{~h}+$ ultrasonic sonification & Boen et al. (2007) \\
Maize flour & $\mathrm{H}_{2} \mathrm{O}_{2}: \mathrm{HNO}_{3}$ & heating until the complete loss of colour(does not mention time) & Santos et al. (2015) \\
\hline
\end{tabular}


Fast method to determine the elements in maize flour: reduction in preparation time and reagent consumption Kelte Filho, I. et al.

Table 5. LD, LQ and the linear regression parameters at a confidence level of $95 \%$.

\begin{tabular}{ccccc} 
& \multicolumn{4}{c}{ Linear Regression parameters } \\
\cline { 2 - 5 } Metal & $\boldsymbol{F}_{\text {regression }}$ & value of $\boldsymbol{p}$ & LD & 0.02 \\
$\mathbf{F e}$ & 13557.36 & 0.000 & 0.01 & 0.13 \\
$\mathbf{M n}$ & 313.98 & 0.000 & 0.04 & 0.02 \\
$\mathbf{Z n}$ & 3354.23 & 0.000 & 0.01 & 0.02 \\
$\mathbf{C a}$ & 18845.77 & 0.000 & 0.01 & 0.04 \\
$\mathbf{M g}$ & 489.83 & 0.000 & 0.01 & 0.08 \\
\hline
\end{tabular}

Table 6. Results for the percent recovery of $\mathrm{Ca}, \mathrm{Cu}, \mathrm{Fe}, \mathrm{Mg}, \mathrm{Mn}$ and $\mathrm{Zn}$ in maize flour samples at levels of 0.5 and $1.0 \mathrm{mg} / \mathrm{L}$ and the values for repetitiveness and intermediate accuracy of the proposed method.

\begin{tabular}{|c|c|c|c|c|c|c|}
\hline \multirow{2}{*}{ Metal } & \multirow{2}{*}{$\begin{array}{l}\text { Concentration added } \\
\text { (mg/L) }\end{array}$} & \multirow{2}{*}{ Recovery (\%) } & \multicolumn{2}{|c|}{ Repetitiveness } & \multicolumn{2}{|c|}{ Intermediate accuracy } \\
\hline & & & $\mathrm{mg} / \mathrm{kg}$ & RSD \% & mg/kg & RSD \% \\
\hline \multirow{2}{*}{$\mathrm{Ca}$} & 0.5 & $109.0 \pm 4.2$ & \multirow{2}{*}{$29.52 \pm 0.887$} & \multirow{2}{*}{3.00} & \multirow{2}{*}{$27.09 \pm 3.672$} & \multirow{2}{*}{13.55} \\
\hline & 1.0 & $93.0 \pm 3.8$ & & & & \\
\hline \multirow{2}{*}{$\mathrm{Cu}$} & 0.5 & $110.0 \pm 6.7$ & \multirow{2}{*}{$0.482 \pm 0.026$} & \multirow{2}{*}{5.39} & \multirow{2}{*}{$0.457 \pm 0.017$} & \multirow{2}{*}{3.72} \\
\hline & 1.0 & $98.0 \pm 1.2$ & & & & \\
\hline \multirow{2}{*}{$\mathrm{Fe}$} & 0.5 & $98.0 \pm 3.1$ & \multirow{2}{*}{$4.291 \pm 0.129$} & \multirow{2}{*}{3.01} & \multirow{2}{*}{$5.927 \pm 0.574$} & \multirow{2}{*}{9.68} \\
\hline & 1.0 & $110.0 \pm 5.3$ & & & & \\
\hline \multirow{2}{*}{$\mathrm{Mg}$} & 0.5 & $96.0 \pm 2.8$ & \multirow{2}{*}{$28.31 \pm 1.342$} & \multirow{2}{*}{4.74} & \multirow{2}{*}{$31.85 \pm 2.60$} & \multirow{2}{*}{8.16} \\
\hline & 1.0 & $97.0 \pm 2.4$ & & & & \\
\hline \multirow{2}{*}{$\mathrm{Mn}$} & 0.5 & $110.0 \pm 4.2$ & \multirow{2}{*}{$0.587 \pm 0.019$} & \multirow{2}{*}{3.24} & \multirow{2}{*}{$0.651 \pm 0.06$} & \multirow{2}{*}{9.22} \\
\hline & 1.0 & $101.0 \pm 1.3$ & & & & \\
\hline \multirow{2}{*}{$\mathrm{Zn}$} & 0.5 & $108.0 \pm 5.6$ & \multirow{2}{*}{$0.486 \pm 0.017$} & \multirow{2}{*}{3.50} & \multirow{2}{*}{$0.428 \pm 0.029$} & \multirow{2}{*}{6.77} \\
\hline & 1.0 & $106.0 \pm 2.5$ & & & & \\
\hline
\end{tabular}

a lack of fit, since the values observed for $F$ were lower than the values for $F=3.71$, and $p>0.05$. The LD and $\mathrm{LQ}$ limits were below the values of the first point on the analytical curves for $\mathrm{Ca}(0.3 \mathrm{mg} / \mathrm{L}), \mathrm{Cu}(0.1 \mathrm{mg} / \mathrm{L}), \mathrm{Fe}$ (0.5 mg/L), Mg (0.2 mg/L), Mn (0.1 mg/L) and Zn (0.1 mg/L), demonstrating that the method employed presented good sensitivity for the determination of the samples of interest.

To check the precision of the method employed, standard addition and recovery studies were carried out at two different concentration levels $(0.5 \mathrm{mg} / \mathrm{L}$ and $1.0 \mathrm{mg} / \mathrm{L})$ for each mineral of interest. The recovery varied from $93 \%$ to $110 \%$ for the levels assessed, being coherent with the values established by the AOAC (LATIMER JUNIOR, 2012) of $80 \%$ to $110 \%$ (Table 6 ). The reliability of the method developed was analysed by carrying out an accuracy study to determine the repetitiveness and intermediary accuracy (ANVISA, 2003). The repetitiveness of the method was determined by analysing the same sample in triplicate on the same day for all of the metals of interest. The intermediate accuracy was determined by carrying out the analyses on three consecutive days, the samples being digested and analysed in triplicate. The values found in the accuracy study presented RSD (\%) values below those indicated by the AOAC (LATIMER JUNIOR,
2012) of up to $7.3 \%$ for repetitiveness and up to $15.0 \%$ for intermediate accuracy (Table 6), demonstrating that the method presents adequate precision and accuracy.

\section{Conclusions}

The methodology developed and validated to determine $\mathrm{Ca}, \mathrm{Cu}, \mathrm{Fe}, \mathrm{Mg}, \mathrm{Mn}$ and $\mathrm{Zn}$ in maize flours presented satisfactory results in accordance with the parameters established for the validation of methods, and can be used in routine analyses to determine different metals in maize flours. The digestion time (1:30 h) was far shorter in relation to the procedures applied in calcination processes, which may vary from $10 \mathrm{~h}$ to $24 \mathrm{~h}$. The elimination of $\mathrm{H}_{2} \mathrm{O}_{2}$ in the sample preparation significantly reduced the introduction of contaminants and the loss of analyte due to the sudden effervescence of the digestion mixture. Finally, sonification of the digested part in an ultrasonic bath ensured full dissolution of the analytes.

\section{Acknowledgements}

The authors are grateful to CAPES (Coordenação de Aperfeiçoamento de Pessoal de Nível Superior) and UNICENTRO (Universidade Estadual do Centro-Oeste). 
Fast method to determine the elements in maize flour: reduction in preparation time and reagent consumption Kelte Filho, I. et al.

\section{References}

AGÊNCIA NACIONAL DE VIGILÂNCIA SANITÁRIA - ANVISA. Resolução RE n 899, de 29 de maio de 2003. Guia para validação de métodos analíticos e bioanalíticos. Diário Oficial [da] República Federativa do Brasil, Brasília, DF, 2 jun. 2003. Available at: <www.anvisa.gov.br>. Accessed on: 7 aug. 2016.

ALGÜL, I.; KARA, D. Determination and chemometric evaluation of total aflatoxin, aflatoxin B1, ochratoxin A and heavy metals content in corn flours from Turkey. Food Chemistry, v. 157, p. 70-76, 2014. PMid:24679753. http://dx.doi.org/10.1016/j. foodchem.2014.02.004.

ASSOCIAÇÃO BRASILEIRA DAS INDÚSTRIAS DE MILHO ABIMILHO. São Paulo, 2015. Available at: <http://www.abimilho. com.br>. Accessed on: 7 Aug. 2016.

BASTOS, E. Guia para o cultivo de milho. São Paulo: Ícone, 1987. $190 \mathrm{p}$.

BOEN, T. R.; SOEIRO, B. T.; PEREIRA FILHO, E. R.; LIMAPALLONE, J. A. Avaliação do teor de ferro e zinco e composição centesimal de farinhas de trigo e milho enriquecidas. Revista Brasileira de Ciências Farmacêuticas, v. 43, n. 4, p. 589-596, 2007. http://dx.doi.org/10.1590/S1516-93322007000400012.

CALLEGARO, M. G. K.; DUTRA, C. B.; HUBER, L. S.; BECKER, L. V.; ROSA, C. S.; KUBOTA, E. H.; HECKTHEUR, L. H. BECKER, L. V.; ROSA, C. S.; KUBOTA, E. H.; HECKTHEUR, L. H. Determinação da fibra alimentar insolúvel, solúvel e total de produtos derivados do milho. Ciência e Tecnologia de Alimentos, v. 25, n. 2, p. 271-274, 2005. http://dx.doi.org/10.1590/S0101-20612005000200015.

CIOBANU, C.; ȘLENCU, B. G.; CUCIUREANU, R. FAAS determination of cadmium and lead content in foodstuffs from north-eastern Romanian Market. StudiaUniversitatis "Vasile Goldiş". Seria ŞtiinţeleVieţii., v. 23, n. 1, p. 33-38, 2013.

COMPANHIA NACIONAL DE ABASTECIMENTO - CONAB. Brasília, 2015. Available at: <http://www.conab.gov.br/>. Accessed on: 8 Oct. 2016.

CUNNIFF, P. (Ed). Official methods of analysis of Association of Official Analytical Chemists. 3rd ed. Gaithersburg: AOAC, 1997.

FATOKI, O. S.; BAMIRO, F. O. Levels of $\mathrm{Na}, \mathrm{K}, \mathrm{Ca}$ and $\mathrm{Mg}$ in infant formulae and in corn-flour infant feeds. Food Chemistry, v. 37, n. 4, p. 269-273, 1990. http://dx.doi.org/10.1016/03088146(90)90107-F.

FERREIRA, A. C. B.; ARAÚJO, G. A. A.; PEREIRA, P. R. G.; CARDOSO, A. A. Características agronômicas e nutricionais do milho adubado com nitrogênio, molibdênio e zinco. Scientia
Agrícola, v. 58, n. 1, p. 131-138, 2001. http://dx.doi.org/10.1590/ S0103-90162001000100020.

HARIRI, E.; ABBOUD, M. I.; DEMIRDJIAN, S.; KORFALI, S.; MROUEH, M.; TALEB, R. I. TALEB. R. Carcinogenic and neurotoxic risks of acrylamide and heavy metals from potato and corn chips consumed by the Lebanese population. Journal of Food Composition and Analysis, v. 42, p. 91-97, 2015. http://dx.doi. org/10.1016/j.jfca.2015.03.009.

HONGXING, Z.; YU-KUI, R. Determining mineral elements in four kinds of grains from Beijing market by ICP-MS simultaneously. Journal of Saudi Chemical Society, v. 16, n. 1, p. 31-33, 2012. http://dx.doi.org/10.1016/j.jscs.2010.10.014.

INTERNATIONAL CONFERENCE ON HARMONISATION - ICH. Validation of analytical procedures: methodolody, Q2B (CPMP/ ICH/281/96). Switzerland: ICH, 1996.

LATIMER JUNIOR, G. W. (Ed.). Official methods of analysis of Association of Official Analytical Chemists. 19th ed. Arlington: AOAC, 2012. Appendix F.

NATIONAL ASSOCIATION OF TESTING AUTHORITIES - NATA. Guidelines for the validation and verification of quantitative and qualitative test methods. Australia: NATA, 2012.

POURHOSSEIN, A.; SHALAEI, M. Determination of total iron in corn and wheat samples by electrothermal atomic absorption spectrometry after solid phase preconcentration. Analytical Chemistry, v. 16, n. 14, p. 104, 2016.

SANTOS, A. M. P.; LEAO, D. J.; SANTOS, L. O. Homogeneity study of a corn flour laboratory reference material candidate for inorganic analysis. Food Chemistry, v. 178, p. 287-291, 2015. PMid:25704713. http://dx.doi.org/10.1016/j.foodchem.2015.01.024.

SANTOS, E. E.; LAURIA, D. C.; PORTO DA SILVEIRA, C. L. Assessment of daily intake of trace elements due to consumption of foodstuffs by adult inhabitants of Rio de Janeiro city. The Science of the Total Environment, v. 327, n. 1-3, p. 69-79, 2004. PMid:15172572. http://dx.doi.org/10.1016/j.scitotenv.2004.01.016.

SCHWANZ, T. G.; MOHR, S.; PORTE, L. M. F.; ZANATTA, N.; BONACORSO, H. G.; MARTINS, M. A. P.; COSTABEBER, J. H. Determinação de bifenilos policlorados em milho através de extração em fase sólida seguida de cromatografia a gás acoplada à espectrometria de massas. Química Nova, v. 35, n. 3, p. 553-558, 2012. http://dx.doi.org/10.1590/S0100-40422012000300021.

TEJERA, R. L.; LUIS, G.; GONZÁLEZ-WELLER, D.; CABALLERO, J. M.; GUTIÉRREZ, A. J.; RUBIO, C.; HARDISSON, A. Metals in wheat flour; comparative study and safety control. Nutricion Hospitalaria, v. 28, n. 2, p. 506-513, 2013. PMid:23822705. 